\title{
Bio-weapons and Bio-terrorism Attacks on Commercial Shipping in Nigeria: The Potential Trojan Horse of the 21st Century
}

\author{
Abdulrazaq O. Abdulkadir \\ Department of Private \& Property Law \\ Faculty of Law, University of Ilorin, Nigeria \\ kor181law@gmail.com \\ DOI: https://doi.org/10.32890/jis2016.12.8
}

\begin{abstract}
Biological attacks by terrorists may seem more like a plot element in an action film than a realistic threat. The possibility of biological weapons attack could be very remote. Scholars are divergent in their opinions on the plausibility of a biological attack. The U.S. Office of the Director of National Intelligence and the National Intelligence Council stated in 2008 that bio-terrorism is a more likely threat than nuclear terrorism. Researches have revealed that of all weapons of mass destruction, biological weapons constitute the greatest worry. The most likely target for bio-terrorism is a major city or other densely crowded areas, such as transportation hubs like sea ports. This paper probes into Nigerian legislations especially the Nigerian Port Authority Act, the NIMASA Act, the Terrorism Act and the NAFDAC Act regarding biological weapons and bio-terrorism in maritime commerce parlance. It is observed in this paper that all these Acts lack preventive mechanisms in the case of the emergence of the scourge. It is argued that Nigeria is vulnerable to bio-terrorism owing to a dearth of detective measure in the boarder ports. The paper concludes that there is an urgent need to revamp the legal framework to tame the threat of bio-terrorism.
\end{abstract}

Keywords: Bio-weapons, bio-terrorism, shipping.

\section{Introduction}

Biological warfare is the premeditated use of one or more biological agents in warfare. It is also known as germ warfare whereby biological toxins or infectious agents like bacteria, viruses and fungi are used with intent to kill or incapacitate humans, animals or plants (Ohiare, 2014). It has been stated that biological weapons have the potential to generate a level of destruction of loss of life even far in excess of nuclear, conventional or chemical weapons. Therefore, biological-terrorists may use bio-weapons in shipment as it were on the battle field (Koenig 2006).

On the other hand, bio-terrorism is the use of one or more biological agents in terrorist activities. It is a criminal act against unsuspecting and innocent civilians using pathogenic biological agents, such as biological warfare agents (Nicolson). Biological warfare is a 
state-supported activity, that is, the perpetrator is a country, whereas bio-terrorism is not and it can be the action of an organisation, such as Al Qaida, Boko-Haram, a cult, or simply an individual.

Furthermore, biological warfare can be used against humans, livestock, or plant crops, but bio-terrorism is almost exclusively employed against humans. Disease is a large killer of humans, but the difference between biological warfare or bio-terrorism and naturally occurring disease is premeditation (Brown, 2008). Thus, a single bio-terrorist is capable of knocking out several targets long before an attack is suspected. This is because most biological agents would need an incubation period of several days in order to cause sickness. Certainly this has the advantage of allowing a bio-terrorist time to escape or accomplish other undetected acts of terrorism (Dasilva, 1999; Das \& Kataria, 2010). Bio-weapon is no doubt another possible and serious threat to maritime security which has not been given sufficient attention in Nigeria.

\section{Hindsight on Biological Weapons and Bio-Terrorism}

The use of biological and chemical weapons is prohibited with the signing and ratification of the "Protocol for the Prohibition of the Use of Asphyxiating, Poisonous or Other Cases and of Bacterial Methods of Warfare" and the "Convention on the Prohibition of the Development, Production and Stockpiling of Bacteriological and Toxin Weapons and on Their Destruction" of 1925 and 1972 respectively (Graham, 1991).

A frightening inventory of attacks by communicable diseases could be extended to other forms of infectious agents, but the key issue here is that although seaborne containers do convey cargo to the designated ports, they are more appropriate as vectors for other forms of disturbing terrorist threats than for others, particularly nuclear weapons and bombs (Cohen, 2006). It has been argued that chemical weapons are more capable of triggering destructive auto-immune reactions and would therefore constitute the most horrifying chemical weapons that serve as nerve agents such as a series of terrible attacks which are most effectively released in air at rail terminals, confined spaces, crowded subways, theatres, sports arenas, etc. where the weapon could kill thousands of people. Bio-terrorism can be transported across borders even in a simple glass bottle, handbag, backpack, suitcase or even the pocket (Cohen, 2006).

Although the use of bio-weapons was banned according to international law by the General Protocol of 1925, the 1972 Biological and Toxin Weapons Convention (BWC) extended the prohibition to almost all production, storage and transport of bio-weapons. (Robert, 2005; Ohiare, 2014). Nevertheless, both the Soviet Union and Iraq who were signatories to the 1972 convention secretly defied the treaty and continued research and production of offensive biological weapons. Specifically, in the 1990s, Iraq admitted to United Nations inspectors that it had produced thousands of tons of concentrated botulinum toxin and had 
developed bombs to deploy large quantities of botulinum toxin and anthrax. Of course, it was stated that the Iraqi government had abandoned its bio-weapons program after the first Iraq war; it was impossible to ascertain the status and whereabouts of the large quantities of the infectious material they developed (Martin, Christropher, \& Eitzen, 2007). This goes to show that regardless of the prohibition of production, storage and transport of bio-weapons, terrorists will make use of them to perpetrate acts of bio-terrorism. In Nigeria, apart from the fact that the Terrorism Act mentions that bio-terrorism is prohibited, (Terrorism Act 2011) no other provision addresses the occurrence and what more of the penalty thereto. Therefore, there is a need for legal regulation and precautionary measures that should reduce the calamity of the release of the diseases among the populace.

Biological weapons and bio-terrorism are not a 21 st century concerns. Historically, basic forms of biological warfare have been practised in the olden days (Ohiare, 2014). It was reported that during the 6th century BC, the Assyrians poisoned enemy wells with a fungus that would make the enemy delirious. Also, in 1336, there was an attempt to infect overwhelmed city dwellers, Mongol attackers, in what is now the Ukraine, used catapults to hurl the bodies of bubonic plague victims over the city walls of Caffa (Martin, Christropher, \& Eitzen, 2007).

In 1763, it was reported that British officers discussed plans to willfully transmit smallpox to Native Americans during Pontiac's Rebellion near Fort Pitt (present day Pittsburgh, Pennsylvania). There is no evidence as to whether they actually carried out these plans but it was certain that smallpox did spread among the natives Americans in the area during and after that rebellion (Martin, Christropher, \& Eitzen, 2007). Also, in 1785, Tunisian forces used plague-tainted clothing as a weapon in the siege of La Calle. Similarly, in 184 BC, Hannibal of Carthage was said to have had-clay pots filled with venomous snakes and instructed his soldiers to throw the pots onto the decks of Pergamene ships (Ohiare, 2014). There were reports that during World War I, German attempted to ship horses and cattle injected with disease-producing bacteria such as Pseudomonas pseudomallei and Bacillus anthraces to the U.S.A and Russia (Ohiare, 2014).

In the same vein, the Japanese in the late 1930s and 1940s used plague as a biological weapon during the Sino-Japanese War. The Japanese filled bombs with plague-infected parasites and dropped them from airplanes into two Chinese cities (Ohiare, 2014). They also used cholera and shigella as weapons in other attacks whereby an estimated 580,000 Chinese people died as a result of the Japanese bio-weapons program.

The use of a bio-terrorist attack was adopted by terrorists in 1984 at Dalles, Oregon, the United States of America, when the Rajneshe cult wanted to spread Salmonella typhimurium at restaurant salad bars in order to prevent voters from voting so that their candidates in the local election could be elected. It was stated that about 750 people were affected, although they were lucky not to have died and the perpetrators were prosecuted (Brown, 2008). 
Recently, a U.S. biological attack occurred after the Al Qaeda attacks of September 11, 2001 (This attack was perpetrated on the World Trade Center and the Pentagon.). What actually happened was that an unknown actor posted a powder containing infectious anthrax microorganisms to two U.S. senators and several media outlets. Five people died from anthrax microorganisms after their exposure to the material in the letters. It was also stated that 17 became ill. Medical personnel offered the anthrax vaccine as post-exposure prophylaxis (PEP) to 1,727 potentially exposed people who were also taking antibiotics to counter anthrax. Out of these people, 199 agreed to take the vaccine and received all the doses (Martin, Christropher., \& Eitzen, 2007).

It has been said that the reason for the attraction of the use of this weapon is attributed to the freedom of accessibility to a range of disease-producing agents, lack of detection by security systems, low cost of production, etc. (Dasilva, 1999; Das and Kataria, 2010). Bioterrorism attacks create havoc in a country through the use of microbes (microbes are living organisms too tiny to be seen with naked eyes except through the use of microscopes and they are related with infection of diseases, bugs, germs etc.) and one of the agents of bioterrorism is anthrax.

(Recently, there was an attack in Japan by the Shinrik Jo cult. Although this was a chemical attack, the Tokyo attempt by this same group was an anthrax and spore at the imperial palace, Dasilva, 1999) which affects the skin and where it is inhaled; the period of incubation is 5 days and death follows. Plague and cholera are also in use by the attackers and these take 1 to 4 days and 5 days respectively for incubation. Although certain measures have been taken in other parts of the world to tackle this problem, there is no evidence of a preventive mechanism in the NIMASA Act in Nigeria and it is the sole agency for maritime security. The enforcement capacity of the NIMASA appears to be restricted to physical approaches to maritime security. The U.S had passed a law to take care of this type of insurgence since 2002 in its Public Health Security and Bio-terrorism Preparedness and Response Act of 2002 (the Bioterrorism Act).

Thus, the possibility of bio-terrorism is real (Das \& Kataria, 2010) considering the costs involved in the production of this destructive weapon. Ironically, the detection of bioterrorism takes a reasonable period of time before the victims know when it was launched by the attackers and this was the situation with 'Legionnaires' diseases which happened after the American Legion Convention of 1976. It indeed took several months before the cause of the infection was discovered (Brown, 2008). The figure below represents the cost of production of bio-terrorism vis-à-vis other weapons as carried out by Brown and the equivalent Naira is included in this research. The cost of production of the bio-weapon is insignificant if compared with either the conventional warfare or chemical weapon. Hence, there is a need to take urgent measures to address the menace. 
Bio-weapons and Bio-terrorism Attacks on Commercial Shipping in Nigeria: The Potential Trojan Horse of the 21st Century

The cost of producing toxic and micro-organism compared with other weapons

\begin{tabular}{cccc}
\hline S/N & Weapons & Cost (USD) & Cost (Naira) \\
\hline 1. & Conventional Warfare & 2,000 & N600,000 \\
2. & Chemical & 600 & N180,000 \\
3. & Biological & 1 & N300 \\
\hline
\end{tabular}

Source: Brown . L. R. (2010)

Note- The calculation is a rough estimate and may not represent the actual official exchange rate.

\section{Conceptual Scrutiny}

The U.S. Office of the Director of National Intelligence and the National Intelligence Council in 2008 argued that bio-terrorism is a more likely threat than nuclear terrorism. In the same year, McConnell Mike who was the Director of National Intelligence revealed that of all the weapons of mass destruction, biological weapons were his personal greatest worry (McConnell, 2008). Arguing in this direction, other defense experts and scientists opined that the likelihood of any attack, especially a large-scale one, is small. For example, the technical difficulties in aerosolizing a disease agent and dispersing it accurately and widely while maintaining its virulence are immense. Nevertheless, most biosecurity experts acknowledge and contend that the potential of an attack should not be ignored. According to the latter position, planning for a biological attack will likely benefit the response to other kinds of public health emergencies (McConnell, 2008).

It has been argued that terrorism is both a political and security challenge (Donohue, 2009). According to this argument, taken from the security perspective, terrorist groups are diffusely organised and operate outside normal diplomatic practices, thereby making them difficult to confront with symmetric (Abdulkadir, 2014; Nirmala, 2012) military resources (Donohue, 2009). No doubt, a lot of resources have been committed to degrade attacks from terrorist groups like the Boko-Haram in Nigeria. For example, in Nigeria billions of dollars have been spent to fight Boko-Haram insurgents, yet the resources were hardly felt until recently, partly due to the serious zero-tolerance to corruption of the present administration. Before the current administration, Boko-Haram became brutal in the preceding administration because of the embezzlement of funds meant for the procurement of arms and ammunition to combat the insurgency (Akioye \& Ehikioya, 2016). It was disheartening to witness some high ranking officers of the Nigerian Armed Forces (Army, Navy and Air force) returning looted funds by way of a plea bargain after their arraignment in courts. Some looted funds were discovered in the soak-away of one of these Military officers. This incredible selfishness made Boko-Haram insurgents appear triumphant and caused the country thousands of lives, kidnapping of young girls, destruction of multi-billion properties to mention but a few. In recent times, the government's struggle to develop mechanisms to reach compromise 
with terrorist groups was witnessed recently in Nigeria when the federal government seeks to dialogue with Boko-Haram leaders in order to ensure peaceful co-existence in the Northeast. This also goes for an attempt to dialogue with the Niger-Delta Avengers to secure maximum protection of oil installations in the Niger-Delta region (on many occasions, these political attempts to resolve conflicts have not materialized owing to leadership crises among the terrorist groups). Where the latter perspective is implemented, governments often promise amnesties and other incentives to terrorist groups (Hayes et al., 2003). It is disturbing as to what could have caused the attacks on innocents. These attacks sometimes have political colourations, thereby making immediate and unconditional demands of certain things. Terrorists often use suicide attacks to draw attention to their issues (William, 2006) as was the case in the height of the Boko-Haram insurgency.

Importantly, governments need to be firm while addressing or negotiating with terrorists. This is because a government which tends to make substantive concessions under threats of terrorist groups is likely to experience more terrorism than governments who hold a firm policy about incident management and demonstrate resolve overtime (Hayes E. Richard). It is against this backdrop that paradox of face (Donohue, 2009), paradox of dispossession and paradox of irrationality are essential tools while undertaking this dimension.

Paradox of face means that the identity of the terrorists or their leader must be ascertained in order to have concrete agreements to curtail excesses of attackers. The inability of the Nigerian government to identify the leader of Boko-Haram is one of the clogs militating against negotiation with the group. Paradox of dispossession means a win-win situation where none of the parties will be seen to triumph. For example, the request by Boko-Haram for the release of their members in custody in return for the release of Chibok girls falls under this category. No doubt this process yielded results in Nigeria which culminated in the release of 21 Chibok girls. While paradox of irrationality means that whoever is engaged by the government to negotiate with insurgent groups must not be temperamental. The negotiator must possess a repository of wisdom to listen and agree on reasonable terms.

\section{Types of Terrorist Groups}

Every terrorist has an individual identity and what sustains terrorist groups are beliefs and attitudes that form the terrorists' identity driven majorly by ideology (Martha, 1988; Bruce, 1999). The major terrorist groups with their ideologies include:

1. The nationalist-separatist: This type of terrorist group attempts to establish a separate political state according to ethnic or political criteria. For example, the Moro Islamic Liberation Front (MILF) attempts at Laha Datu to realize the Bangsamoro nation and thereby claim sovereignty over Sabah which is part of Malaysia. Also in this category are the Irish Catholic Republican Terrorists who are Roman Catholics, and the Popular Front for Liberation of Palestine. The Biafra agitators of Nigeria cannot be placed under this category because 
they have not been declared as a terrorist group and their actions have not suggested terrorism, yet the clamoring for cessation could be categorized as political separatists. This category of terrorist group often develops into criminal organizations with training and experience in terrorism. The community legitimizes this activities of the group as the fighting is for their cause. Hence, except where necessary, violence is seldom used as the group typically planned their operation (Silke Andrew, 2003).

2. The Social Revolutionist: This group uses terrorism as a means of drawing attention to themselves and pressurizing the government to change certain social or economic policies. One of the characteristics of this group is that it possesses a certain degree of interdependence with the government. Also, the group focuses on fighting for the improvement of a policy they were partly the architect and always avoid any act that would reduce their public patronage or sympathy (Wilson).

3. The Religious Fundamentalist: This group is considered a "Sacramental act" as members carry out their dastardly activities with the impression of theological benefits (Hoffman, 1999). While seeking their demands, this group causes damage to society. For example, the Boko-Haram insurgents in Nigeria seek to forbid western education, thereby bombing schools, religious houses, markets, and kidnapping innocents girls (Abdulkadir, 2014). Apart from the arguments by Islamic scholars who have opposed Boko-Haram insurgents on western education, the ideas of the insurgents are barbaric because Islam as a religion enjoins seeking knowledge. Allah says:

"And that those who have been given knowledge may know that it (this Qur'an) is the truth from your Lord, and that they may believe therein, and their hearts may submit to it with humility. And verily, Allah is the Guide of those who believe, to the Straight Path".(Suratul al-Hajj: 54).

In the same vein, Allah forbids the killing of innocents in the Quran as follows: "That was why we laid down for the children of Israel that whoever killed a human being, except as a punishment for murder or for sedition on the earth, should be looked upon as though he had killed a mankind, and that whoever saved a human life should be regarded as though he has saved all mankind" (Al- Quran. Al Maidah 5:32.).

Similarly, in the case of Kalu v. State, (1998) 13 NWLR Pt.583, the court held that life is sacrosanct and deliberate killing is abhorred in all societies the world over. What this provision means is that everyone is entitled to respect his or her life and safety.

Bearing the above in mind, bio-weapons and other nuclear weapons are perhaps the most terrible to contemplate in the sphere of trans-boundary security which attackers/terrorists adopt in dealing with their victims. Bio-terrorism is a kind of airborne communicable 
disease, like smallpox, that could kill millions of citizens as well as spread around the neighborhood of a country of their target. Rather than export the harmful and dangerous cargo in a container at boarder ports, terrorists equipped with bio-weapon like smallpox would likely find it convenient to infect a few willing suicide attackers/terrorists and send them by ship to the country they intend to perpetrate havoc.

Bio-weapon is a serious weapon of destruction potentially imported through the boarder ports and before anyone could know what is happening or before any symptoms manifest, the bio-weapon would have been released by attackers who might have pretended to be passengers on board the ship and thousands of innocent citizen would have been affected (Cohen, 2006). A container conveyed by ship would be a serviceable import vector and most likely serves as carrier to transport the canister across borders to the trusted terrorist/ attacker. This potential danger is vulnerable in Nigeria owing to the dearth of detective measures to combat the menace of trans-boundary harm through containers. Containers have been said to be well suited for important roles in other types of attacks that make use of chemical weapons creating terror and triggering reactions that cause severe economic damage (Abdulkadir, 2013).

Thus, a potential danger of bio-weapon was evidenced in the Santa Clara I, off the eastern coast of the United States in January 2002, when there was a storm which caused several containers containing magnesium phosphide to spill their contents in the hold. This content when mixed with water and or air, forms two highly reactive gases - phosphene and diphosphane - that can explosively auto-ignite at ambient temperatures. In the case of the Santa Clara I, the magnesium phosphide containers were improperly manifested thereby hiding the dangerous nature of their contents. This case of mislabeled containers is not a unique occurrence and because of the constraints placed on water-hazardous compound handling and stowage both in ports and on ships, some unscrupulous shippers and forwarders ambiguously and/or mislabel containers containing these compounds. A container loaded with fertilizer (ammonium nitrate) could create a blast 10 times than that of the Oklahoma City bombing. As a result, priority for deterring and detecting chemical weapons must, in any realistic scheme of things, be increased to levels of effort far in excess of those based on the direct damage such weapons are likely to cause, because sociopolitical factors must be considered. A collection of chemicals, that when mixed can cause explosions and release poisonous gas, could be packed in separate canisters in a container and the same thing could be done in several such containers, all scheduled to arrive in different inland locations within several days or even weeks. Manifests, which detail the containers' contents, could be falsified; this is not such an infrequent occurrence (Cohen, 2006).

Sometimes, the application of bio-terrorism kills beyond the usual as the number might be quite large. From the totality of the research conducted, Nigeria lacks the legal and regulatory framework to tackle the menace of bio-terrorism (Ohiare, 2104). It is humbly posited that legal, biological and technological framework be put in place to address/cushion the situation in the event of its occurrence. The Organization for Economic Cooperation and Development (OECD) tracked down two exemplary incidents (Cohen, 2006). In November 
2002, a container exploded onboard the container ship Hanjin Pennsylvania, causing extensive damage. The cause was found to be improperly packed, improperly loaded and improperly documented fireworks and calcium hypochlorite (a bleaching agent used in swimming pools) in the containers

\section{Power to Regulate Influx of Bio-Weapons and Bio-Terrorism}

Generally speaking, a port state is allowed under international laws to regulate the entry or access the conditions of the ships to its ports (Konig, 2010; Kasoulides, 1993). Port security is indispensable to international commercial growth. The continued development of legitimate international commerce is not without its bad story, hence the growth has been accompanied with criminal activities and purposes. Threats to maritime security have been witnessed in a series of ways and these threats range from smuggling of drugs, weapons, (including WMD), people, contrabands as well as armed robbery and piracy. Incidents of maritime crime occurred most especially in the areas of heavy commercial maritime movement (Shelton). This holds true particularly where there is significant economic and political instability such as in Nigeria, or in regions with diminutive or no maritime law enforcement competence (Shelton). It is not in doubt that the perpetrators of port and maritime insecurity are usually well prepared and equipped with modern weapons, communications and high-speed craft. The capabilities of these criminals to board, release lethal or nonlethal agents, hijack and or seize large underway vessels were all demonstration of the extent of numerous biological weapons, bio-terrorism and piracy incidents. The question is whether the Nigerian Maritime Administration and Safety Agency (NIMASA), the Nigerian Port Authority (NPA), the National Agency for Foods and Drugs Administration Control (NAFDAC) and other maritime security agents are imbued with the necessary skills and machine to contain the occurrence of biological weapons and bio-terrorism in our maritime ports or domains. There is no doubt that the absence of necessary skills and machine to prevent the occurrence of biological weapons and bio-terrorism could also be employed to facilitate terrorist acts.

It merits mentioning that, as a general rule, under international law, the port of every state is presumed to be open to all commercial vessels but the same international law also permits an exception if the vital interest of the state concerned will be jeopardized (Sohn and Noyes, 2004). A port state also enjoys the right of conditioning access to foreign-flagged commercial vessels to its port, and the authority of the government of the port state to deny access to ships during the time of war has also been widely acknowledged (Sohn and Noyes, 2004). Therefore, a port state will reserve the right to deny access to a foreign ship where the ship breaches the following;

1. Failure to comply with the rules and regulations for the conduct of the business of the port under the 1923 Convention; Article 3.

2. Involvement of the vessel in the transportation of hazardous material against the provisions of the 1923 Convention and the 1982 UNCLOS; Article 17 and Article 211 respectively. 
3. Nuclear-powered ships by virtue of the 1962 Convention on Liability for Operators of Nuclear Ships.

Essentially, a port state may curtail the port access to all foreign ships, subject to any rights of entrance clearly granted under the applicable treaties identified above and those ships in distress owing to force majeure (Sohn and Noyes, 2004; O'Connell, 1984). In the same vein, it is the assumption of the international law that access to a port will not be restricted by the port state to foreign-flagged commercial vessels or that the port state will not impose sanctions upon the foreign-flagged vessels other than those designed to promote or ensure the security and safety at both the entry and the departure of the ships in the course of navigation and conducting business in the port state (O'Connell, 1984).

It is certain that a weapon like bio-terrorism, nuclear device, etc. could cause enormous social and environmental disruption and destroy important infrastructure including private and non-port facilities (Haveman and Shatz, 2006). Therefore, a state while exercising the right jurisdiction on the foreign-flagged vessels when the vessels are within the port state's water must conform to well recognized and fundamental principles of international law (O'Connell, 1984). The import of this, as far as the importation of bio-weapons or bioterrorism is concerned, is that Nigeria in an attempt to exercise power on foreign ships for maximum security of the country must comply with the principles of the customary international law. Hence, doing otherwise would be tantamount to arbitrary and unreasonable exercise of the port state's sovereignty over foreign-flagged ships. It also would give rise to series of redress including retaliatory restrictions, diplomatic protests, dispute settlement procedures, liability for damages etc. This was the situation in The Mary Poppins case, 19 Jahrb. Int. R. (1976), 139, when a shipping company in Germany proposed a ferry service between Southampton and St. Malo in 1975 wherein the French union prevented the service from operating, notwithstanding the government's undertaking and clearance that the crew would be half French and half British. The German shipping company took legal action and the tribunal held that the company had the right of free entry under both the community and international laws to St. Malo and because of the fact that this had been denied, the company was entitled to damages from the French state.

In order to ensure that bio-weapons are not imported into the country, the Nigerian Port Authority, the National Agency for Control of Foods and Drugs Administration Control, and the Nigerian Maritime Administration have immense roles to play.

\section{Role of the Nigerian Port Authority (NPA)}

Nigeria, as a port state, in an effort to combat biological weapons and bio-terrorism requires a ship to supply information before departure to the country and this must be done not later than 30 days prior to the arrival of the vessel. This in a way allows the designated agents of the government to prepare for the inspection of the incoming vessel. It is mandatory that the 
ship furnish the Nigerian Port Authority with a written statement indicating the name and physical particulars of the incoming vessel, the name of the port of arrival, the estimated time of departure and arrival in Nigeria and detailed information with respect to the cargo carried in the ship (Section 114, NPA Act). No ship is allowed to enter Nigeria without the prior approval of the authority (Section 116). Importantly, where the master of the ship fails to comply with above provisions of the law, he shall be guilty of an offence which shall be liable upon conviction to 2 years imprisonment (Section 119). Therefore, apart from this notification strategy, the Act appears to be silent on any other modality for the port security in Nigeria, although the bringing of dangerous goods or substances to the port premises is strongly prohibited (Section 6 (1), (2) and (3) of the Nigerian Port Authority is Docks and Premises Bye-Laws). However, it needs be emphasized that the fine specified as fine for the breach of the provision is ridiculous; the perpetrator or those who trade in biological weapons and hazardous or dangerous goods would prefer to part with the paltry sum of \#100 as fine or even escape with the goods and infiltrate the nation with tribulations. Therefore, an onward review of the penalty will serve as a deterrent to the offenders.

As a key policy goal, all states must cooperate to develop and implement efficient and effective conditions on port access to ensure the security of the port state and the international commercial system. Overly restrictive conditions would have a deleterious effects on global trade and the world's economy. However, overly permissive conditions on entry, such as faulty cargo screening, could result in a security breakdown and a devastating terrorist attack on a port city. Such a disaster renders virtually inconsequential the debate over restrictions on port access to achieve political, environmental, safety, law enforcement, or other goals. Even so, international lawyers and policy-makers must seek to ensure that access to the ports of the world is fundamentally free and only restricted by conditions directly, effectively, and reasonably related to the significant interests of the port state and the world community at large (Oliver, 2009).

\section{Role of the Nigerian Agency for Food and Drug Administration Control (NAFDAC)}

The National Agency for Food and Drug Administration and Control (NAFDAC) is an agency of the Federal government whose task is to safeguard public health. This agency must ensure that only the right quality food, drugs and other related products are manufactured, exported, imported, advertised, sold and used (Section 5 (a), NAFADAC Act). It is established by the National Agency for Food and Drug Administration and Control Act. Important functions of NAFDAC relevant to this research are the control of the importation, exportation, manufacturing, distribution, sale and use of medical devices and chemicals. Medical devices as used in the NAFADAC Act could be conveniently construed to mean biological weapons which breed bio-terrorism.

The implication of this is that NAFDAC is competent to station its officers at boarder ports for the purpose of preventing the importation of biological weapons into Nigeria. In 
fact, NAFDAC is imbued with powers to conduct appropriate tests and ensure compliance with the standard specifications designated and approved for effective control of quality medical devices and chemicals (Section 5 (b) NAFDAC Act and Omolokun,). However, the question is, can officers of NAFDAC stationed at boarder ports for the purpose of preventing importation of biological weapons into Nigeria possess the necessary tools to respond to emergency biological threats? What formed this question is that there is evidence that a typical vaccine required to treat emergency biological threats might be in development and clinical trials for 10 to 20 years before licensure (Arnon, 2001).

Therefore, for NAFDAC to succeed with this daunting experiment, there a need for it to control the pathway to the licensure for vaccines, treatments and diagnostic tests that will respond to bio-weapons. The NAFDAC Act may be amended to empower the agency to control the pathway to licensure and this was the situation in the United States (see U.S Vaccine Development, Testing, and Regulation). By the U.S practice, where a new vaccine is needed urgently, the Food and Drug Administration has developed rapid alternative pathways to licensure. There are two alternatives pathways in this perspective and these are:

1. Accelerated Approval Path: One of the alternative pathways is an accelerated approval path that might apply in a situation where a life-threatening disease with an unlicensed vaccine that has meaningful therapeutic benefit over existing options.

2. Animal Rule: This applies in a situation where a more drastic threats occurs, the animal rule may be invoked. Where a research toward a vaccine indicates the possibility of exposing humans to a toxic threat, then animals will be used as experiment. Although, till date these two rapid pathways are yet to be invoked for vaccines owing to the absence of some of these disease agents (bio-weapons) in the natural world where they could be tested. Therefore, the best method of unveiling this path is through animal.

Where these two identifiable measures are adopted, apart from fact that it would address bio-weapons and bio-terrorism in shipping, it would have served as an impetus to curb a scourge like the Ebola endemic that ravaged the counties in 2014.

It is also appropriate to state that there is a need to enlighten the populace on the abuse of chemical toxins while carrying out laboratory experiments in order to avert the experience of misuse happening in the agrochemical industry. It is a common practice among farmers during storage to see pesticides being used for fishing. Also in use is the inappropriate application of pesticides on stored products such as beans and grains to prevent insect infestation, misapplication of chemicals to fruits like bananas to ripen them or to vegetables such as carrots and cabbages to control insect infestation (Omolokun). The experience of Zamfara state of Nigeria which caused the death of dozens of infants and children is a clear demonstration of the poor attention given to toxic metals in the food consumed in the SubSaharan Africa (Omolokun). 


\section{Conclusion}

Bio-weapon is no doubt possible and indeed constitutes a serious threat to the shipping industry in Nigeria but it has not been given sufficient attention. Bio-terrorism being a willful use of micro-organisms and toxins to wit plant, animal origin, microbal, etc. to produce disease, the result of which is death in humans. Although chemical weapons are capable of triggering destructive auto-immune reactions, bio-weapons can be transported by terrorists across borders even in a simple glass bottle, handbag, backpack, suitcase or even the pocket. The reason for the attraction of the use of this bio-weapon is attributed to the freedom of accessibility to a range of disease-producing agents, lack of detection by security systems and, low cost of production. It is the opinion of this research that since there is no evidence of a preventive mechanism in the NIMASA, the NAFDAC and the Terrorism Prevention Acts in Nigeria, it has become imperative to enact or amend the law to take care of this type of insurgence. It is humbly suggested that the Nigerian government should improve on the lapses identified in this research and bridge the gap in the legal regime. Nigeria can take a cue from the U.S which has passed its Public Health Security and Bio-terrorism Preparedness and Response Act since 2002.

\section{References}

Aliu, A., Ohiare. (2014). Awareness of biological warfare in Nigeria. International Letters of Natural Sciences, 18, 47.

Abdulkadir, A.O. (2014). Asymmetric maritime security threats: A factor in the Nigerian terrorism eccentricity. NIALS Maritime Law Journal, 2, 43-69.

Abdulkadir, A.O. (2013, July-December). Preventing armageddon: Implementation of the international ship and port facility security (ISPS) code in Nigeria. Ife Juris Review, (Journal of Contemporary Legal and Allied Issues), IFJR, Part 2, pp. 349.

Al-Quran Surah al-Hajj: 54.

Al-Quran. Surah Al Maidah 5:32.

Arnon S. A. et al. (2001). Botulinum as a biological weapon: Medical and public health

management. JAMA, 285(8), 1059-1070. Retrieved from http://jama.ama-assn.org/ content $/ 285 / 8 / 1059$

Brown, L. R. (2014, October). The impact of bio-terrorist attack on shipping and potential remedial measures. In Forbes .A, (Ed.), 104.

Challenges in the use of anthrax vaccine adsorbed (AVA) in the pediatric population as a component of post-exposure prophylaxis (PEP). (2011). Being a report of the National Biodefense Science Board. October 2011. Retrieved from http://bepast.org/ disease_information/Anthrax/avwgrpt-111025.pdf

Cohen, S. S. (2006). Boom boxes: Containers and terrorism. In Haveman, J. D \& Howard

J. S. (Eds.), Protecting the Nation's Seaports: Balancing Security and Cost. California:

Public Policy Institute of California, 91-92.

Crenshaw Martha. (1998). The subjective reality of the terrorist: Ideological and

psychological factors in terrorism. In Robert, O. Slater and Michael Stohl (eds.), Current 
Perspectives of International Terrorism, London, Macmillan Press. See also, Hoffman Bruce, Inside Terrorism. New York: Columbia University Press. Dasilva, E. J. (1999). Biological warfare, bio-terrorism and the biological and toxin weapons convention. Electronic Journal of Biotechnology, 2 (3), 3(December 15), 99. Das, S., \& Kataria, V.K. (2010). Bio-Terrorism: A public health perspective. MJAFI, 66 (3), 256.

D. Konig. (2010). Flag of ships Heidelberg and Oxford University Press, p.9, See also George C. Kasoulides. (1993). Port state control and jurisdiction: Evolution of the port state regime (Maltnius Nijhoff Publishers) p.1. It needs to be emphasized that warships and the government are entitled to immunity.

D. P. O'Connell. (1984). The International Law of the Sea, Vol. II I.A.Shearer (Ed.) New York: Clarendon Press, p. 853.

Graham. T, Jr. (1991). Limitation on chemical and biological weapons. In Stephan III P.B and Klimenko B.M, (Eds.), International Law and International Security: Military and Political Dimensions, (United States of America: M.E.Sharpe Inc.), 115 and 141. Haveman J. D., \& Shatz, H. J. (2006). Introduction and summary. In Protecting the nation's seaports: Balancing security and cost, Jon D. Haveman and Howard J. Shatz (Eds.). (California: Public Policy Institute of California), p.2. Hayes, E. Richard. (2002) Negotiating with terrorists. In Victor Kremenyuk (Ed.), International Negotiation. San Francisco, C.A, Jossey-Bass, 416-430.

Hayes et al. (2003). Negotiating the non-negotiable: Dealing with absolutist terrorists. International Negotiation, 8, 9-24.

Jane Omolokun. (2013, April). Regulation and enforcement of legislation on food safety in Nigeria. Mycotoxin and Food Safety in Developing Countries, 256.

John, T. Oliver. (2009). Legal and policy factors governing the imposition of conditions on access to and jurisdiction over foreign-flag vessels in U.S. Ports. South Carolina Journal of International Law and Business, 5(209), 210-211.

Koenig, R. (2006). The fourth horseman: One Man's Secret campaign to fight the great war in America, Public Affairs.

Garth L., Nicolson, Bioterrorism and biological warfare agents, http://www.immed.org/ illness/bioterrorism.html

Lewis, R. Brown. (2008). The impact of a bio-terrorist attack on shipping and potential remedial measures. In Andrew Forbes (Ed.), Asian energy security: Regional cooperation in the Malacca Strait, (Sea Power Centre, Australia), 103.

Louis B. Sohn, \& John E. Noyes. (2004). Cases and materials on the law of the sea (New York, Transitional Publishers), 363. Louis B. Sohn, \& John E. Noyes, id, p.395.

Lynne D. Shelton. (2007). The ebb \& flow of the United States coast guard: Our forgotten heroes in times of crisis. Retrieved from http://works.bepress.com/lynne_shelton/1 Martin, J.W., Christropher, G.W., \& Eitzen, E.M., Jr. (2007). History of biological weapons: From poisoned darts to intentional epidemics. In Dembek, ZF. (Ed.), Medical Aspects of Biological Warfare, Office of the Surgeon General, Borden Institute. http://www.cs.amedd.army.mil/borden/Portlet.aspx?ID=66cffe45-c1b8-4453-91e0$9275007 \mathrm{fd} 157$

McConnell, M. (2008) Remarks \& Q\&A by the director of national intelligence. 
http://www.dni.gov/files/documents/Newsroom/Speeches\% 20 and $\% 2$ Interviews/20081202_speech.pdf (111 KB)

NAFDAC Act. (2004). Cap. N1, Laws of the Federal of Nigeria.

Nigeria Port Authority Act. (2004). Cap.126 Laws of the Federation of Nigeria, section 114.

Nirmala, J. (2012, July 12). Responses to non-traditional threats \& challenges.

Reconnecting India and Central Asia, Traditional security challenges.pdf accessed on, p.82. Robert, F. (2005). Deterring terrorism: It can be done. International security on biological weapons, 30, 95-98.

Segun Akioye \& Augustine Ehikioya. (2016, August). Buhari: Arms funds scam extended Boko Haram's reign. The Nation.

Silke Andrew. (2003). Becoming a terrorist, in Andrew Silke (Ed.), Terrorists, victims and society: Psychological Perspectives on Terrorism and its Consequences. Chichester,

U.K, Wiley, pp.29-53.

The Nigerian Ports Authority Docks and Premises Bye-Laws. (204). Cap. 126 Law of the Federation Nigeria, section 6 (1), (2) and (3).

Terrorism Act 2011, section 1 (2) (c) (v).

U.S Vaccine Development, Testing, and Regulation

William, A. D. (2009). Terrorism and conflict resolution. In Jacob Bercovitch, Victor

Kremenyuk and I. William Zartman (Eds.), Conflict Resolution, London: Sage

Publication, p. 437.

Wilson Margaret A. (2000). Toward a model of terrorist behaviour in hostage-taking incident. Journal of Conflict Resolution, 44 (4),403-423.

Zartman, I., William. (2006). Negotiating with terrorists: Introduction. In Zartman, I.

William. (Ed.), Negotiating with Terrorists. Leiden, the Netheland: Martinus Nijhoff Publishers, pp. 1-8.

1923 International Regime of Maritime Ports, Article 3.

1966 Load Lines Convention and MARPOL 73/78.

1982 Convention on the Law of the Sea.

1962 Convention on Liability for Operators of Nuclear Ships. 